\title{
First fossil manatees in Texas, USA: Trichechus manatus bakerorum from Pleistocene beach deposits along the Gulf of Mexico
}

\author{
Christopher J. Bell, William Godwin, Kelsey M. Jenkins, and Patrick J. Lewis
}

\begin{abstract}
Extant manatees were documented on the Texas coastline as early as 1853 , but their reported occurrence in Texas waters has been sporadic and poorly documented until relatively recently. We report eight specimens that document the first occurrence of fossil manatees in Texas, and the westernmost fossil occurrence of manatees in the United States. Seven of the specimens were collected along McFaddin and Caplen beaches on the northwest coast of the Gulf of Mexico; one was recovered from Corpus Christi Bay. The fossil specimens reported here include a mandibular symphysis fragment diagnosable as the extinct morphotype denoted by the trinomial Trichechus manatus bakerorum Domning, 2005. Other specimens are diagnosed as Trichechus manatus or as Sirenia. They were found on beaches that are known to produce mammalian taxa characteristic of Pleistocene faunas, and our age assessment is based on that association, and the comparable preservation, color, and density of the manatee bones and bones of extinct taxa of Pleistocene age from the beaches. It is not clear whether the fossils represent remains of a resident population, or the fortuitous preservation of vagrant individuals. However, assuming that the ecological tolerances of manatees in the Pleistocene were comparable to the tolerances of extant populations, the presence of manatees in the northwest Gulf of Mexico in the Pleistocene adds an interesting, if enigmatic, data point for paleoenvironmental reconstructions of the region.
\end{abstract}

Christopher J. Bell. Jackson School of Geosciences, The University of Texas at Austin, Austin, Texas 78712, USA. cjbell@jsg.utexas.edu

William Godwin. Sam Houston State Natural History Collections, Sam Houston State University, Huntsville, Texas 77341, USA. wbg004@shsu.edu

Kelsey M. Jenkins. Department of Earth and Planetary Sciences, Yale University, New Haven, Connecticut, 06520, USA. kelsey.jenkins@yale.edu

Bell, Christopher J., Godwin, William, Jenkins, Kelsey M., and Lewis, Patrick J. 2020. First fossil manatees in Texas, USA: Trichechus manatus bakerorum from Pleistocene beach deposits along the Gulf of Mexico. Palaeontologia Electronica, 23(3):a47. https://doi.org/ $10.26879 / 1006$

palaeo-electronica.org/content/2020/3178-pleistocene-manatees-in-texas

Copyright: September 2020 Society of Vertebrate Paleontology.

This is an open access article distributed under the terms of the Creative Commons Attribution License,

which permits unrestricted use, distribution, and reproduction in any medium, provided the original author and source are credited.

creativecommons.org/licenses/by/4.0 
Patrick J. Lewis. Sam Houston State Natural History Collections, Sam Houston State University, Huntsville, Texas 77341, USA and Department of Biological Sciences, Sam Houston State University, Huntsville, Texas 77341, USA. pjl001@shsu.edu

Keywords: Sirenia; Texas; McFaddin Beach; Caplen Beach; Pleistocene; Rancholabrean; Fauna

Submission: 12 June 2019. Acceptance: 17 September 2020.

\section{INTRODUCTION}

The West Indian manatee (Trichechus manatus) is the only extant representative of the mammalian order Sirenia in North America. It is a fully aquatic species of mammal with a relatively large adult body size; total length of adult manatees ranges from 2.5 to over $4.5 \mathrm{~m}$, with mass up to 650 $\mathrm{kg}$, but averaging about $200 \mathrm{~kg}$ (Jones and Johnson, 1967). Their year-round distribution in the waters off the coast of the United States is centered on the southern part of peninsular Florida, but their summer range extends north along the Atlantic coast, and west along the northern portion of the Gulf of Mexico. Manatees are rare along the coastal waters of Texas, but have been found there sporadically since the mid-1800s.

Pleistocene fossil vertebrates were first discovered on the beaches between Galveston and the Louisiana border in the early 1960s, and early systematic collections were reported by Long (1977). Pleistocene sirenians were not previously reported from Texas, but we document eight fossil specimens that were collected between 1967 and 1990. All specimens are now curated in the Sam Houston State Natural History Collections at Sam Houston State University in Huntsville, Texas, and in the Jackson Museum of Earth History at the University of Texas at Austin. These specimens represent the first record of Pleistocene manatees in Texas and mark the westernmost recorded fossils of Trichechus manatus in the United States. We describe the new fossils below and contextualize them in the broader historical and ecological record of extant manatees in the northwestern Gulf of Mexico.

\section{BIOGEOGRAPHY OF MANATEES IN THE UNITED STATES}

\section{Extant Manatees}

Extant manatees occupy estuarine and freshwater habitats along the Atlantic and Gulf coasts of the Florida peninsula (Deutsch et al., 2003; Fertl et al., 2005). Manatees most commonly are found in estuarine and river-mouth settings, but also can be found in brackish water that is in close proximity to freshwater sources. Manatees are able to maintain ionic and osmotic homeostasis in a variety of aquatic habitats, but may need to conserve sodium when in freshwater habitats for extended periods of time (Ortiz et al., 1998). Their year-round range is restricted to the warmer waters of southern Florida, but in the summer months they migrate north along the Atlantic coast, where they are regularly sighted in the coastal waters off Georgia and South Carolina (Lefebvre et al., 2001). Records from North Carolina have been reported for nearly 90 years (H. Brimley, 1931; C. Brimley, 1946; Schwartz, 1995; O'Shea, 1988:198), and sightings in the waters off of Virginia date back over a century (Nelson, 1916) and may extend back as far as 1676 (McAtee, 1950). Long-range seasonal migrations along the Atlantic coast were documented by Deutsch et al. (2003) and Fertl et al. (2005). In 1996 one individual was documented by radio telemetry to travel from Florida to the waters adjacent to Rhode Island (Reid, 1997; Lefebvre et al., 2001).

Manatees from coastal waters of the United States along the Gulf of Mexico long presented a biogeographic puzzle for mammalogists. The earliest reported specimen from the Gulf Coast west of Florida is a skull and skeleton of a young animal (True, 1884b; Gunter, 1941b). It was collected by then-Lieutenant Darius N. Couch and was shipped to the Smithsonian Institution in Washington, D.C. in March 1853, accompanying the Jean-Louis Berlandier collection that Couch had just purchased from Berlandier's widow (Lawson, 2012). The manatee specimen was accessioned with that collection and was originally catalogued as USNM A1375 (the ' $A$ ' being a designation used for specimens that entered the collections early in the history of the museum; the ' $A$ ' designation is no longer used). The locality data for the specimen were noted by Gunter (1941a, b) to be somewhat ambiguous. Specimen records in the Smithsonian indicate it was taken 'from Brazos,' but Gunter concluded that the source appears to be Brazos de Santiago Island at the extreme southeastern end of 
Texas, not the Brazos River to the north. This conclusion is supported by the fact that Couch arrived at Brazos de Santiago in February of 1853 and had his base of operations in that vicinity in the early months of that year (Lawson, 2012). The specimen collected by Couch, and the comments by Silas Stearns (quoted by True, 1884b) that according to "the oldest settlers" manatee bones could be found all along the Gulf Coast shore "everywhere that civilization has not reached" (True, 1884b:114), led Frederick True to argue that manatees once ranged across the northern Gulf Coast "perhaps as far as the Mississippi River" (True, 1884a:6), though he doubted any lived in the region at the time he wrote, with the possible exception of Texas. No confirmation ever emerged of the characteristically blackened bones mentioned by Stearns from the salt water sand-beaches along the Gulf Coast (Gunter and Corcoran, 1981:98).

Prior to 1970 there were no documented occurrences of manatees from Alabama or Mississippi, but there was one from Louisiana, one from the Texas-Louisiana border, and at least nine records from Texas (Powell and Rathbun, 1984; O'Shea, 1988). Manatees have never been considered anything but rare in Texas waters (Gunter, 1941a; Würsig et al., 2000), and most of the Texas records were several decades old when a decomposing carcass of a male washed up on the Bolivar Peninsula near Caplen, Texas, in 1986 and reestablished the occasional presence of manatees in Texas waters (O'Shea, 1988; Fernandez and Jones, 1990). Coastal areas of Texas, Louisiana, Mississippi, and Alabama were all mapped as extralimital range for manatees by Lefebvre et al. (2001:452). Detailed summaries of records along the northern Gulf Coast were provided by O'Shea (1988) and Fertl et al. (2005). The latter documented 377 records from the Gulf Coast west of Florida, only 40 of which had been previously published. They provided dot-distribution maps and an appendix documenting locality descriptions, latitude and longitude, date of observation or collection, and number of individuals for each record. They also noted an increase in records in the decade prior to their writing, suggesting a general trend of increasingly common penetration of manatees into the northwestern Gulf Coast through the latter quarter of the twentieth century.

Sixty-six records of manatees in the waters off the Gulf Coast of Texas were reported by Fertl et al. (2005; Figure 1). Those records included 53 sightings, eight carcasses, and five captures. Of the 66 records, only 21 were previously published

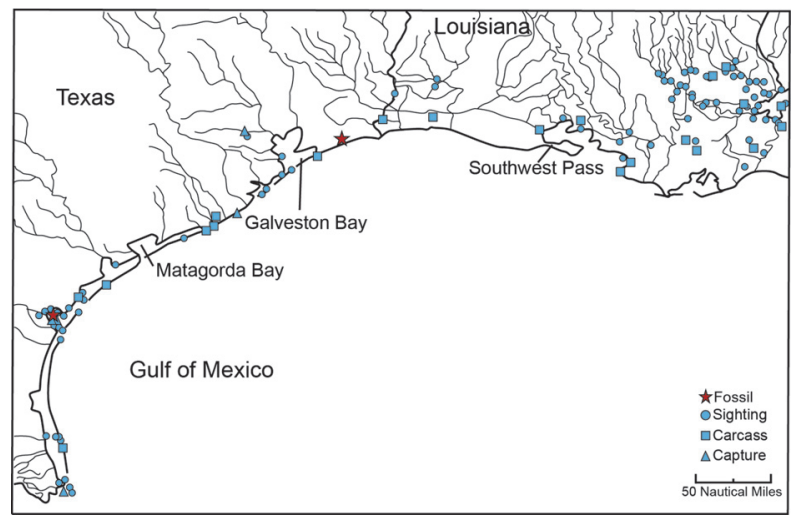

FIGURE 1. Map showing manatee occurrences along the northwestern coast of the Gulf of Mexico. The two red stars mark the locations of fossil specimens from McFaddin Beach (to the northeast) and Corpus Christi Bay (to the southwest). The blue symbols indicate historical occurrences, including sightings (circles), caracasses (squares), and captured specimens (triangles). Historical distribution data are modified from Fertl et al. (2005). North at top.

historical records. Peak years for manatee records from Texas were in 1995 and 2001. October and November were the months with the most reported records (14 and 12, respectively).

Whether Texas manatees represented vagrant individuals from Florida or from Mexico (or both) was a long-standing and open question. Early observers hypothesized that animals from Texas likely originated from southern populations and represented vagrants moving north along the Mexican coastline (True, 1884a; Gunter, 1941a; Moore, 1951a; Lowery, 1974). The historical occurrence of manatees along the Mexican coast from Belize to Texas was noted by Lefebvre et al. (2001), who also reported their virtual disappearance from Veracruz northward during the 1970s and 1980s, suggesting that the decline in sightings of manatees in Texas and their general decline in Mexican waters were possibly related (Lefebvre et al., 2001). The long distance required for Florida manatees to reach Texas waters was noted by Moore (1951a), and the absence of manatee records from the coasts of Alabama and Mississippi posed an interesting biogeographical gap that seemed to support a Mexican derivation for the Texas outliers. Following 1970, more records of extralimital manatees from the northern Gulf Coast west of Florida were documented and filled that gap (Gunter and Corcoran, 1981; Powell and Rathbun, 1984; O'Shea, 1988; see also Lefebvre et al., 2001; Fertl et al., 2005). 
Ultimately, genetic data became available to address the question of biogeographic origin of the Texas manatees. A specimen from Buffalo Bayou near Houston was captured in December, 1995 and was held for a time in San Antonio before being transferred to Florida and ultimately released back into the wild. Genetic analysis of that animal indicated it was a Florida manatee (Fertl et al., 2005), and tissue from a dead specimen found in October, 2001 from Matagorda County was sampled and matched the haplotype of Florida manatees documented by Garcia-Rodriguez et al. (1998; see Fertl et al., 2005).

Concomitant with the elucidation of the broader geographic distribution of manatees along the northern Gulf Coast was an emerging clarity on some of the physical factors that control the geographic distribution of manatees. Of special importance were the factors that permit their survival in that region during winter months. Manatees apparently require regular access to freshwater sources, and although they can traverse brackish waters, open-ocean records are quite rare (Würsig et al., 2000; Fertl et al., 2005), but that rarity possibly is a result of strong bias towards observations being made in coastal settings (Fertl et al., 2005). Records from $12.87 \mathrm{~km}$ and $144.8 \mathrm{~km}$ off the coast of Louisiana are interesting anomalies from the northern Gulf Coast (Gunter and Corcoran, 1981; Fertl et al., 2005). Water depth at the latter locality was $1524 \mathrm{~m}$.

Cold water temperature has long been known as a limiting factor in the distribution of the West Indian manatee (Gunter, 1941b, 1942; Moore, 1951b; Hartman, 1979; O'Shea et al., 1985), and as recently as 1988 definitive statements were made that most manatees that did not return to Florida waters after summer travels would die from exposure to cold water; the few exceptions were those animals that found shelter in anthropogenic warm waters (O'Shea, 1988). The importance of natural (spring) or anthropogenic (e.g., industrial effluent or runoff) warm waters was noted by Würsig et al. (2000) and Lefebvre et al. (2001) who suggested that increases in such water sources likely influenced patterns of distribution and migration in manatees along both the Atlantic and northern Gulf coastlines. The threshold temperature at which manatees seek warmer waters appears to be around $20^{\circ} \mathrm{C}$ (Hartman, 1979; Lefebvre et al., 2001). It is interesting that, in contrast to the early records from the state, the more recent records of manatees from Texas include sightings from the winter months, and those animals were almost invariably found in warmer water 'boat basins' or in areas under the influence of warmer waters derived from power plants (Fertl et al., 2005).

\section{Pleistocene Manatees}

Manatee remains previously were reported from Pleistocene deposits in many localities in Florida, and also are known from the Pleistocene of South Carolina, North Carolina, New Jersey, Louisiana, and from the Arkansas-Mississippi border (Gallagher et al., 1989; Williams and Domning, 2004; Domning, 2005). A specimen from the continental interior near Springfield, Ohio, was associated with dredged material from Pleistocene gravels, but was dated 2,055 + 65 B.P., and may represent a Holocene record (Heisey and Johanson, 1977; Williams and Domning, 2004; Domning, 2005). All of those fossils are referrable to the extant species Trichechus manatus, but many of the Pleistocene specimens are morphologically distinct and were diagnosed as an extinct morphotype that was given the trinomial name Trichechus manatus bakerorum by Domning (2005). Those records clearly indicate that manatees had a broader distribution during at least part of the Pleistocene into the interior of the continent, and a total paleo-distribution comparable to the total known range (including extralimitals) of modern manatees along the Atlantic Coast. Although sirenians were previously reported from Texas from Eocene sediments of the Laredo Formation in Webb and Zapata counties (Domning et al., 1982; Westgate, 1990), the specimens reported here provide the first record of fossil manatees from Texas and are the westernmost records of manatees in the Pleistocene.

\section{RESULTS}

\section{Institutional Abbreviations}

SHSU = Paleontology Collection, Sam Houston State Natural History Collections at Sam Houston State University, Huntsville, TX; TxVP = Vertebrate Paleontology Collections, Jackson Museum of Earth History, The University of Texas at Austin, Austin, Texas (formerly Texas Memorial Museum).

\section{Pleistocene Fossil Collections}

We identified eight fossil sirenian bones from five discrete collections housed at two institutions. Most of the specimens we report made their way into museum repositories via generous donations from private collectors who recognized the scientific importance of their specimens. A single speci- 
men was collected in Corpus Christi Bay, but most of the specimens were collected on McFaddin Beach (Jefferson County, Texas) and Caplen Beach (Galveston County, Texas) in the vicinity of the coastal town of High Island, Texas. All of these collections post-date Hurricane Carla, which made landfall on the Texas Coast in September 1961. The specimens from McFaddin Beach were collected prior to 1990; specimens from Caplen Beach were collected after 1992. An initial donation to Sam Houston State University came from Joe Liggio, and contained recognizable and diagnostic specimens of sirenians from McFaddin Beach. That discovery excited our interest in locating more sirenian material from McFaddin Beach, which is known as a productive locality for beach wash-ups of Pleistocene mammal fossils (Long, 1977; Tveten, 1982) and Paleoindian artifacts (Long, 1986; Bever and Meltzer, 2007). We made contact with long-time resident and outdoorsman Mike Moorhouse, who had a small personal collection of beach fossils but did not possess any sirenian material. Through his efforts, we made contact with two other collectors, Brian Babin and Kit Herrington, each of whom donated sirenian materials housed in their collections. We also identified previously unreported specimens from two collections housed in the vertebrate paleontology collections at the Jackson Museum of Earth History in Austin. A brief history of each collection is provided below.

The Joe Liggio Collection. Joe Liggio is a botanist and environmental scientist in Houston, Texas. He became aware of fossils on the beaches near the town of High Island after reading John L. Tveten's (1982) book Coastal Texas: Water, Land and Wildlife, which illustrated a Pleistocene horse tooth from McFaddin Beach. In 1983 Liggio started finding teeth and bone fragments on visits to the beach. Liggio and his friend Charlie Brooks of Galveston combed the beach east of Highway 124 about monthly between 1983 and 1990, but more frequently in winter. Liggio recalls that collecting efforts were most productive in the fall of 1983 after Hurricane Alicia struck the Texas coast. He stopped collecting fossils around 1990. Liggio's entire fossil collection, including a sirenian mandible fragment, an edentulous dentary, and several rib fragments, was donated to Sam Houston State University in 2017.

The Brian Babin Collection. Brian Babin collected at McFaddin Beach from 1967 to 1975. Babin's collection was derived from beaches between Sea Rim State Park and the town of High Island, and contained a maxilla fragment and some rib fragments. The maxilla fragment was distinctive and was kept with other unidentified bones until we identified it in 2018. The maxilla fragment is described herein; the rib fragments are not. Babin stated that unusual rib fragments were commonly found by collectors on the beach, but were assumed to be whale ribs and referred to as such; at least some of those fragments appear to be manatee bones.

The Kit Herrington Collection. Kit Herrington collected fossils from a different area called Caplen Beach, in Galveston County, approximately $16 \mathrm{~km}$ southwest of the areas where Liggio and Babin collected. Herrington visited the beach at Caplen since childhood in about 1954, but only became aware that people were finding shark teeth on the beach in about 1992. He recalled that hunting for black shark teeth led to his noticing other black bone fragments. Herrington donated his collection to Sam Houston State University in 2018; it contains a single manatee rib bone.

The Texas Vertebrate Paleontology Collections in Austin. There are two sirenian specimens, from two different collections, housed in the Jackson Museum of Earth History. The first collection (locality number 46040) is a small one made by Carolyn Good and Peggy Leshikar as part of a mitigation project associated with the installation of a pipeline. Specimens were collected under permit \#DOE 16536. The collection is associated with the Texas Historical Commission site number 41JF50, which was established in 1978 to accommodate collections made along several miles of McFaddin Beach (Hall, 1998). Field notes record the collection as coming from "Holocene marsh deposits approximately $1 \mathrm{~m}$ below the beach sands." The materials were collected, presumably in situ, in May 1983; there is no date to substantiate the claim for Holocene deposition, and the age of the specimen in unknown. They are curated in the Pleistocene collections at the Texas Vertebrate Paleontology Collections in Austin.

The second collection was derived from the Texas A\&I University collection (later became the Texas A\&M Kingsville collection) that was transferred to Austin in 2014. It is now accessioned under locality 44211 in the Vertebrate Paleontology Collections at the Jackson Museum of Earth History. The collection contains a single rib fragment labelled "Spoil Island near Ingleside Cove." That label indicates an offshore area between Nueces and San Patricio counties, substantially farther to the southwest from McFaddin and Caplen beaches (Figure 1). Spoil Island is located just offshore from 


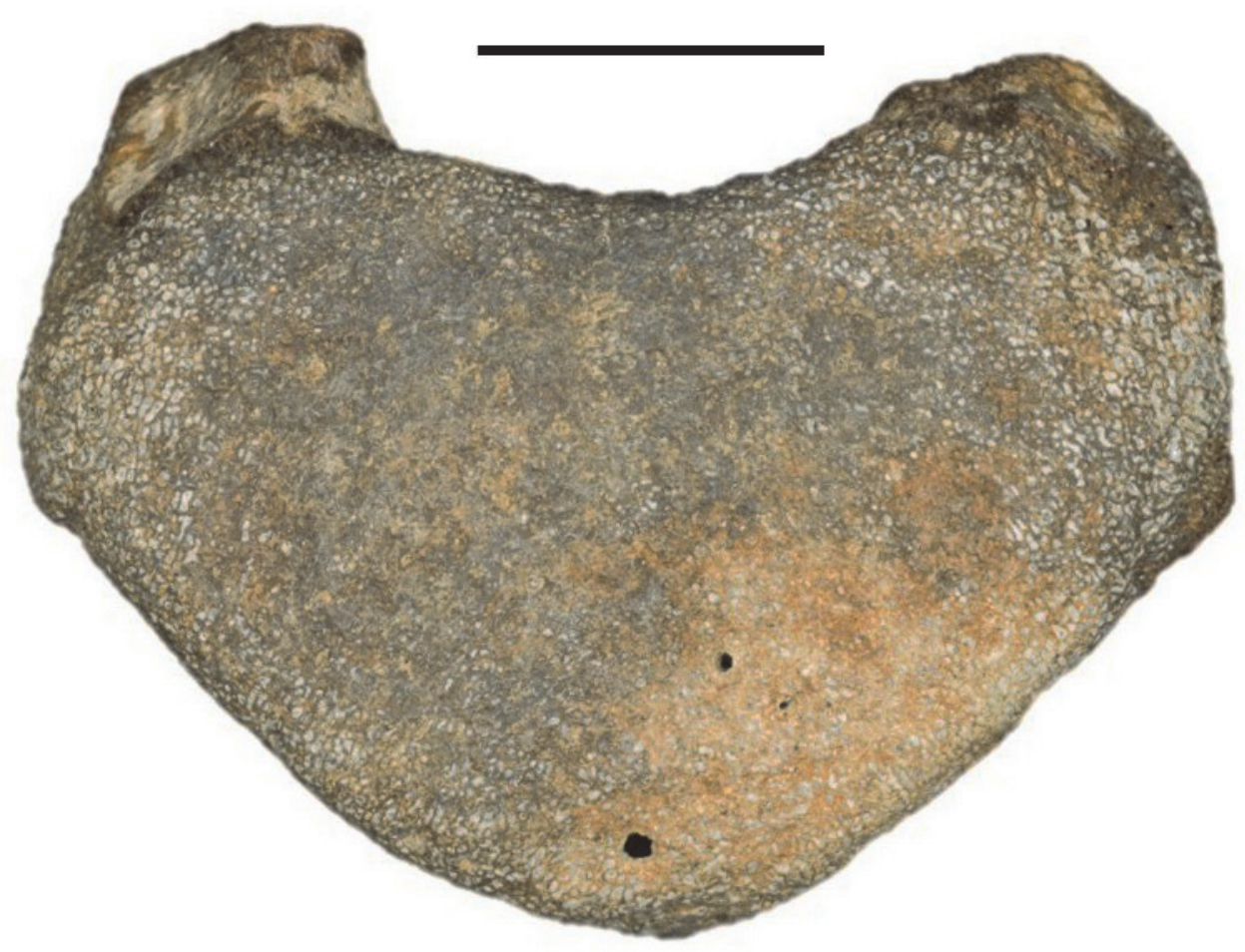

FIGURE 2. TxVP 46040-9, thoracic vertebral centrum. Dorsal to top. Scale bar equals $2 \mathrm{~cm}$.

Corpus Christi, on the west side of Corpus Christi Bay; Ingleside Cove is located on the north side of that Bay, just south of Ingleside. The specimen was collected by John Baskin; a note from Baskin on file in the museum indicates that the specimen was collected "just off the Inglesides, in channel." No specific date of collection is available, but the specimen has a Texas A\&l specimen label. Baskin moved to $A \& I$ in 1982, and $A \& I$ changed its name to A\&M Kingsville on August 31, 1989. Therefore, the specimen was collected between 1982 and 1989.

\section{SYSTEMATIC PALEONTOLOGY}

\section{Class MAMMALIA Linnaeus, 1758 \\ cf. Order SIRENIA Illiger, 1811 gen. et sp. indet. (Figure 2)}

TxVP 46040-9. Thoracic vertebral centrum. The centrum is amphiplatyan, with flat, distinctly heartshaped anterior and posterior surfaces. The heartshaped cross-section of thoracic vertebrae was noted by Quiring and Harlan (1953), and appears to characterize thoracics of many sirenians, but is not uniquely apomorphic to the group. The morphology of this specimen as preserved is com- pletely consistent with referral to Sirenia, but a more refined taxonomic identification is not justifiable. It is from 41JF50 (McFaddin Beach); field notes indicate the specimen was taken from "Holocene marsh deposits approximately $1 \mathrm{~m}$ below the beach sands" in May, 1983.

$$
\begin{gathered}
\text { Order SIRENIA Illiger, } 1811 \\
\text { SIRENIA, gen. et sp. indet. (Figure 3) }
\end{gathered}
$$

SHSU 1-236. Distal rib, $23.2 \mathrm{~cm}$ curvilinear length; maximum diameter $5.6 \mathrm{~cm}$ (Figure 3). Collected on McFaddin Beach; from the Joe Liggio collection.

SHSU 1-233. Distal rib fragment, $14.2 \mathrm{~cm}$ curvilinear length; maximum diameter is $3.8 \mathrm{~cm}$. Collected on Caplen Beach; from the Kit Herrington Collection.

SHSU 1-234. Distal rib fragment, $10.4 \mathrm{~cm}$ curvilinear length; maximum diameter is $4.2 \mathrm{~cm}$. Collected on McFaddin Beach; from the Joe Liggio collection. TxVP 44211-1. Midshaft rib fragment, maximum preserved length is $7.1 \mathrm{~cm}$; maximum diamter is $4.5 \mathrm{~cm}$. Collected from locality 44211, "just off the Inglesides, in the Channel."

Remarks. The rib fragments are pachyosteosclerotic, a condition typical of derived aquatic sirenians (Domning and de Buffrénil, 1991; de Buffrénil et al., 2010) and associated with maintenance of 


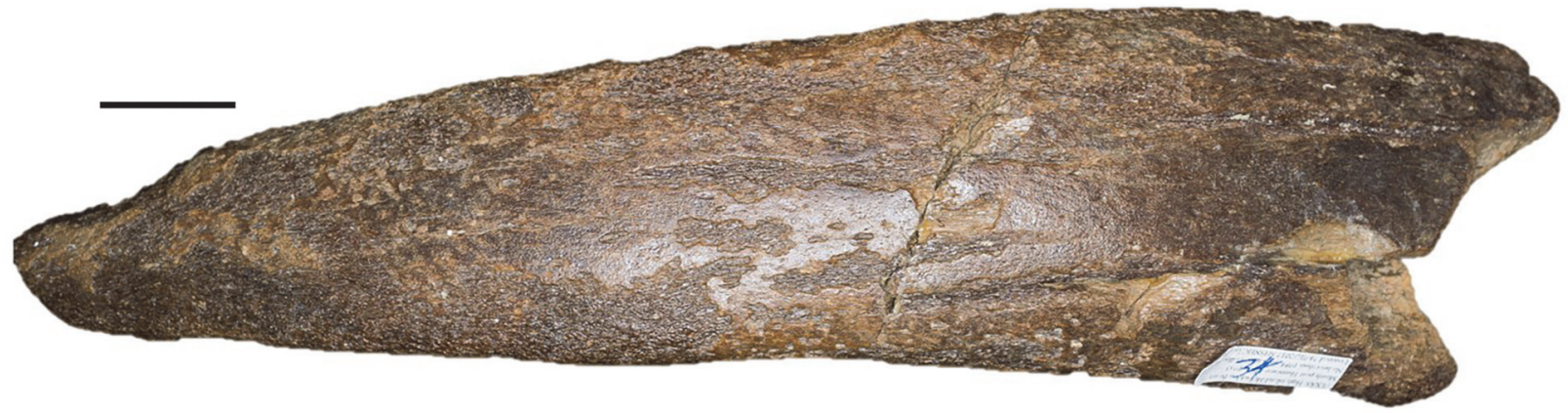

FIGURE 3. SHSU 1-236, distal rib fragment. Scale bar equals $2 \mathrm{~cm}$.

buoyancy (Domning and de Buffrénil, 1991). SHSU 1-236 shows marked expansion along the central portion of the rib shaft, and tapering at the distal end, both characteristic of the ribs of extant sirenians.

Family TRICHECHIDAE Gill, 1872 (1821)

(Form of citation follows International Code of Zoological Nomenclature, Fourth Edition, Recommendation 40A; See International Commission on Zoological Nomenclature, 1999)

Genus TRICHECHUS Linnaeus, 1758 Trichechus manatus Linnaeus, 1758 (Figures 4, 5)

SHSU 1-027. Left edentulous dentary ramus with intact but abraded symphyseal region, labial alveolar surfaces, and posterior margin of the bone intact (Figure 4). The angular process is missing, as is the lingual portion of the alveolar region. Maximum preserved length is $16.5 \mathrm{~cm}$; depth of the dentary at approximate midpoint of the anteroposterior length is $4.9 \mathrm{~cm}$; depth from the top of the coronoid process to the (broken) base of what would be the angular process is $10.4 \mathrm{~cm}$. From the Joe Liggio collection.

SHSU 1-231. Right anterior edentulous maxilla fragment, with a resorbed anterior alveolar region; two complete sets of molar alveoli and part of a third are preserved (Figure 5). Total preserved length is $8.4 \mathrm{~cm}$. From the Brian Babin collection.

The preserved anatomy of SHSU 1-027 allows confident referral to Trichechus manatus, but the portions of the bone that would allow confident referral to T. m. bakerorum, the symphyseal and angular regions of the dentary, are abraded and absent, respectively.

Trichechus manatus bakerorum Domning, 2005 (Figure 6)

SHSU 1-235. Mandibular symphysis, with partial left dentary ramus preserving alveoli for two teeth. The symphyseal region has a relatively shallow dorsoventral depth. The ventral surface is abraded on the left side, but the preserved portion of the right side includes a low, rounded, ventrally projecting boss. The low projection and shallow depth of the mandible at the symphysis are apomorphic and diagnostic of Trichechus manatus bakerorum (Domning, 2005). Depth at the symphyseal line is $4.1 \mathrm{~cm}$; width across the symphysis is $5.2 \mathrm{~cm}$. From the Joe Liggio collection.

\section{GEOLOGY, ASSOCIATED FAUNA, AND AGE}

McFaddin Beach is composed of Recent beach sands and dunes overlying Pleistocene clay and mud deposits of the Beaumont Formation (Aronow, 1971). Fossils recovered from McFaddin Beach are thought to be redeposited from off-shore deposits by ocean currents and wave action (Stright et al., 1999; Arnold and Oertling, 1995), and certainly include extinct mammals typical of Pleistocene faunas. Owing to the mixed nature of beach-deposited material, precise geological age(s) of the fossil specimens of manatees remain uncertain. Our age estimation is based upon the taxonomic composition of fossil mammals collected along the beach (see below), and the comparable preservation, density, and coloration.

During the Quaternary, the shoreline of the Gulf of Mexico regressed over $200 \mathrm{~km}$ as the formation of glaciers lowered the sea level by as much as $120 \mathrm{~m}$ (Anderson, 2007; Simms et al., 2007; Stright et al., 1999). During periods of lowered sea level the Trinity, San Jacinto, Neches, Sabine, and Calcasieu rivers all entered the Gulf of Mexico through a common delta along the eastern Texas coast (Simms et al., 2007). During periods of lower ocean levels the area now encompassed by McFaddin and Caplen beaches was a coastal plain, bordered on the Southwest by the Trinity River and on the northeast by the Sabine River (Simms et al., 2007). Twenty-two thousand years 


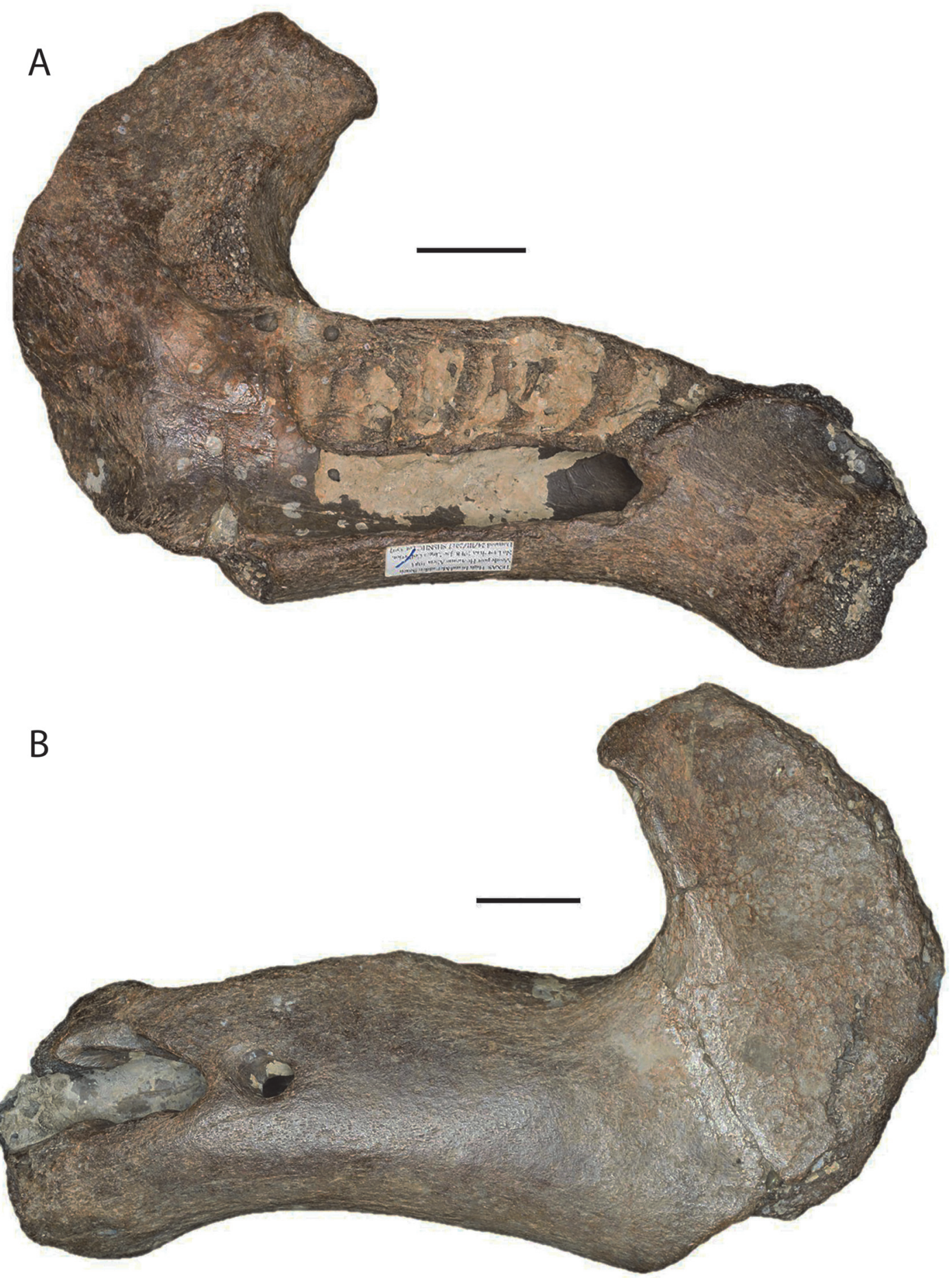

FIGURE 4. SHSU 1-027, edentulous left dentary in lingual (A) and labial (B) views. Scale bar equals $2 \mathrm{~cm}$.

ago the shoreline of what is now Texas was located approximately $129 \mathrm{~km}$ (80 miles) south of its modern extent (Anderson, 2007). As sea levels rose during the Holocene, the Sabine-Neches alluvial valley was drowned (Milliken et al., 2008) and eventually infilled, as were other valleys that drained the then-combined outflows of rivers that today make independent contributions to the Gulf (Anderson et al., 2016; Anderson, 2007; Anderson et al., 1996). The extensive deltaic deposits of the 

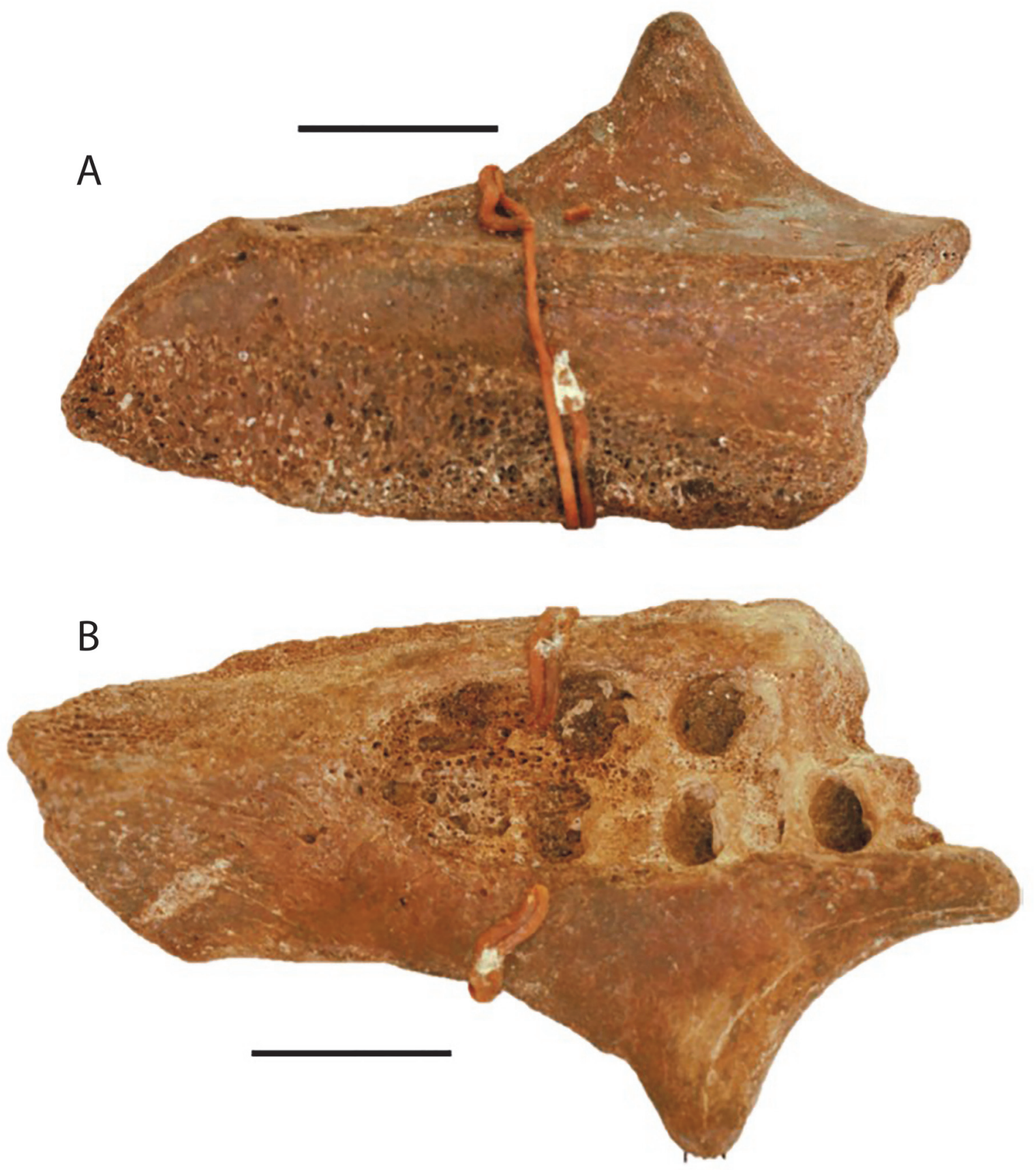

FIGURE 5. SHSU 1-231, edentulous right anterior maxilla fragment in dorsal (A) and ventral (B) views. Note the resorbed anterior alveolar region typical of manatees. The rubber band was not removed because it was considered to be part of the history of the specimen. Scale bar equals $2 \mathrm{~cm}$.

Colorado Delta, Brazos Delta, and Western Louisiana Delta (Anderson et al., 1996) are possible sources for the Pleistocene fossils that have washed ashore over the last 60 years but because of the distances involved from those sources areas, it is more likely that the fossils are derived from the channel-fill and fluvial deposits associated with the ancient and now submerged river valleys (Rodriguez et al., 2004).

Late Pleistocene vertebrate fossils and early Paleoindian artifacts are known to have been recovered since the 1960s from the beaches along the Texas coast between Galveston and the Louisiana border (Long, 1977). Fossil specimens and 


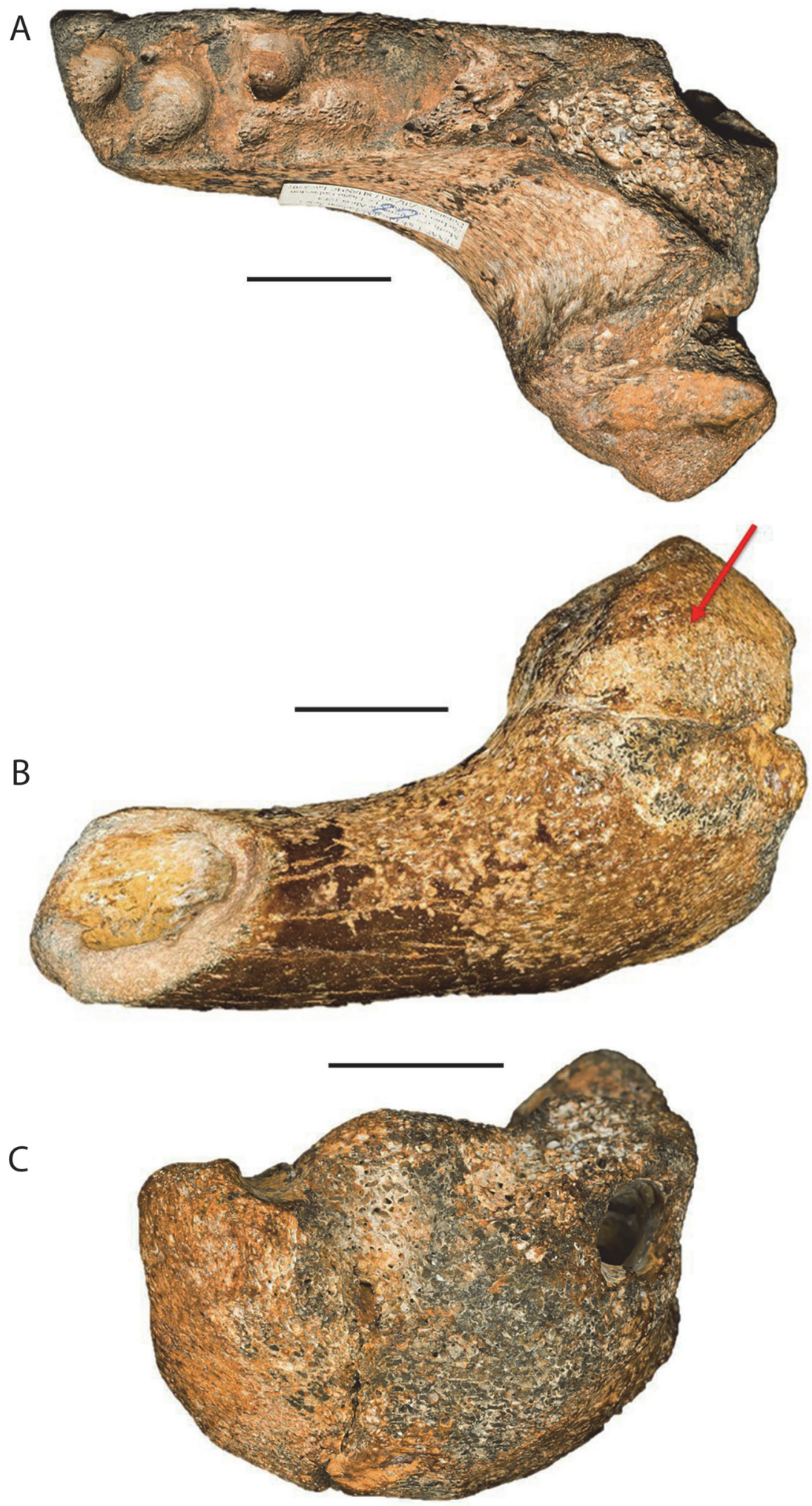

FIGURE 6. SHSU 1-235, mandibular symphysis with partial left dentary ramus in dorsal (A), ventral (B), and anterior (C) views. The shallow dorsoventral depth and low, rounded ventrally projecting boss (arrow) are diagnostic features of the extinct morphotype Trichechus manatus bakerorum. Scale bar equals $2 \mathrm{~cm}$. 
artifacts are known for tens of $\mathrm{km}$ along the Texas beach (Hester et al., 1992; Long, 1986), and McFaddin Beach garnered the attention and focus of archaeologists for decades owing to the large number of Clovis and Paleoindian points found there (Stright et al., 1999; Bever and Meltzer, 2007); the McFaddin Beach area has its own specified archaeological site designation (41JF50).

The presence of Pleistocene fossils and artifacts from McFaddin Beach was first mentioned as part of a description of fossils collected by Odis and Beverly Beckham (Long, 1977). The description included photographs of the stone and bone tools in the Beckham collection, along with general provenience data for the artifacts. Two Clovis points subsequently were described (Long, 1986). Other archaeologists began studying McFaddin Beach lithics, although little attention was paid to vertebrate fossils (Patterson, 2000; Stright et al., 1999).

The Pleistocene fauna from McFaddin Beach was summarized and discussed in an unpublished master's thesis (Russell, 1975). Thirty-eight different taxa were identified, including 30 mammals, four reptiles, and four fishes (Russell, 1975). The most abundant taxa described were Tremarctos floridanus (bear), Sylvilagus sp. (cottontail rabbit), Megalonyx jeffersonii (ground sloth), Tapirus excelsus (tapir, now Tapirus veroensis), and Odocoileus virginianus (whitetailed deer). The fossil materials described by Russell (1975) represent a mixture of taxa characteristic of the Gulf Coast and the Plains, and appear to represent a Rancholabrean fauna. Russell divided the megafauna into the 'extinct group,' the 'extant group,' and the 'recent local group.' The large extinct forms were reported to include Mammuthus columbi, Mammut americanum, Megalonyx jeffersonii, Eremotherium, Tremarctos floridanus, Smilodon, Tapirus excelsus, Tapirus copei, Tanupolama mirifica, Chlamytherium septentrionale (now Holmesina septentrionalis), Neochoerus pickneyi, several species (here interpreted as morphotypes) of extinct horses of the genus Equus, and the peccary genera Mylohyus and Platygonus. Those taxa were extinct by the end of the Pleistocene, ca. 10,000 years B.P. (+- 3,000). Russell's second group included extant vertebrates that no longer inhabit the Gulf Coast of Texas. That group includes Felis onca, Cynomys ludovicianus, and Bison bison. The recent and local vertebrates that made up the third group are Didelphis marsupialis, Procyon lotor, Canis latrans, Lontra canadensis, Sylvilagus, and Odocoileus virginianus.
The majority of taxa recovered from McFaddin Beach, however, are consistent with faunas from the Rancholabrean Land Mammal Age (Russel, 1975), and it is primarily by association with those taxa, and the Clovis points, that the manatee fossils are estimated to be Pleistocene in age. The consensus view is that the Clovis artifacts and the extinct Pleistocene fauna are derived from one or more offshore localities that now are submerged beneath the waters of the Gulf of Mexico. The excellent preservation and general lack of heavy abrasion on these materials argues against longdistance transportation (Bever and Meltzer, 2007; pers. obs.). The sirenian and manatee specimens we report here from McFaddin and Caplen beaches were compared with bones of the extinct Pleistocene taxa Eremotherium sp., Holmesina septentrionalis, Mammuthus columbi, and Equus sp., as well as with modern bones of dolphin, sea turtle, and alligator collected from beaches in the vicinity of Galveston. Evaluation of the coloration of the bones showed that the extinct Pleistocene taxa and the manatee elements have comparable Munsell colors (Munsell Color Co., 1929). All but one of the sirenian bones have Munsell color of 10YR 2/2; one rib fragment has a color of $5 \mathrm{Y} 2 / 2$. The extinct Pleistocene taxa have colors of 10YR 3/2, 10YR 2/ 2 , and $5 Y 2 / 2$. The modern skeletal elements are much lighter in color, with much higher values (= closer to white). In addition, the manatee bones are well mineralized and are considerably denser than modern bones (beyond what would be expected from just pachyosteosclerosis). No numerical dates are available for any manatee elements from the beaches; all are so heavily permineralized that collagen preservation potential is extremely poor.

\section{DISCUSSION}

Of the five collections cited here, three are from McFaddin Beach, but do not overlap in time of collection. The Liggio collection was made between 1983 and 1990. The Babin collection was made between 1967 and 1975, and pre-dates the initiation of the Liggio collection by at least seven years. The Herrington collection from Caplen Beach is from a location $16 \mathrm{~km}$ away and postdates the Liggio collection by at least two years. TxVP 46040 was collected in May 1983. These collections document a history of collecting in three discrete intervals stretching over approximately 30 years and approximately $20 \mathrm{~km}$ of shore.

There is a curious lack of observations or collections from McFaddin Beach prior to 1961. Russell J. Long, professor at Lamar University in 
Beaumont, Texas, was the first to publish on the site. Long joined the faculty of the Department of Biology in 1951 and worked on extant vertebrates of McFaddin Beach for many years before a student alerted him to the presence of fossils and human artifacts on McFaddin Beach (Long, 1977). Long did not cite the specific date of his first fossil collection, but in his 1977 publication he stated that he had been collecting artifacts and fossils for 16 years (Long, 1977). His statement would place his first knowledge about Pleistocene fossils on the shore to about 1961, the year that Hurricane Carla made landfall.

In a study of the spatial distribution of lithic artifacts from McFaddin Beach, Stright et al. (1999:2) stated that local residents had been collecting artifacts on McFaddin Beach "for the last 30 years." This statement would place collections no earlier than 1969.

A keyword search of The Galveston Daily News between 1851 to 1897 (all the available digitized issues) produced 75 articles mentioning fossils and several articles on fossils from the Galveston vicinity, but no mentions of fossils from any beaches, including Bolivar Peninsula, High Island, and McFaddin Beach. Throughout the 1880s the incidence of articles in the Galveston newspaper peaked in rough coincidence with the 'bone wars' of E.D. Cope and O.C. Marsh. During that time the Galveston Daily News printed from one to five articles on fossil discoveries per year. Meanwhile, the beaches around High Island were not remote or un-frequented by vacationers. By 1850, 15 families had settled the area and by 1885 that number had grown to 80 families. By 1882 news stories about fossil discoveries were peaking as mineral springs and a new hotel were attracting tourists to High Island (Wallace, 2015). The lack of information on beach fossils is strange given the common presence of mastodon and mammoth fossils known from there now and the frequenting of the beach by excursionists from the nearby cities of Galveston, Houston, and Beaumont.

The original stratigraphic source(s) of the fossils reported here is offshore, but otherwise unknown. At the time the fossils were deposited, they probably were relatively close to shoreline, which was as much as $129 \mathrm{~km}$ south of its modern position during the late Pleistocene (Anderson, 2007). The source deposit seemingly was exposed and began producing fossils that washed ashore only starting sometime in or around the early 1960 s, possibly as a result of erosive forces associated with Hurricane Carla. The rare occurrence of manatee fossils is noteworthy, as is their occurrence with extinct mammalian taxa clearly characteristic of the Pleistocene. That the manatee fossils remained taxonomically unnoticed may be attributed to the combination of their scarcity, the lack of adequate skeletal specimens of manatees in most museum collections in Texas, and a general lack of understanding that manatees are and have been, even if only rarely, part-time or seasonal visitors to Texas waters today.

It cannot be determined yet if the fossils represent remains of a stable and year-round resident population during some portion of the Pleistocene, or if they represent the serendipitous preservation of rare vagrant animals such as those that have occasionally visited Texas over at least the last 166 years. The lack of detailed age control on the fossils, and the limited resolution of paleoenvironmental reconstructions of water temperature, currents, and the temporal extent of possible warm waters in the Gulf of Mexico mean that our data are insufficiently robust to provide a meaningful interpretive context for Pleistocene manatees in Texas. But if we assume the ecological tolerances of the extant populations, especially with respect to water temperatures and access to fresh water sources, are an accurate reflection of past tolerances, the presence of the animals in the Pleistocene provides a unique opportunity to rethink paleoenvironmental reconstructions in the Gulf Coast region during that interval.

\section{ACKNOWLEDGMENTS}

We thank B. Babin, K. Herrington, and J. Liggio for allowing us access to their collections, and for their donation of the specimens that serve as vouchers for the occurrence of fossil manatees in Texas. We also are grateful to M. Moorhouse for providing access to his collection. All of those men also shared their thoughts and reflections about McFaddin and Caplen beaches, and their recollections about the history of collections in the area. D. Mohrig greatly enhanced our understanding of offshore geology in the vicinity of the Texas coast. J. Baskin brought to our attention the specimen he collected near Corpus Christi, and C. Sagebiel pointed out the small collection of material from McFaddin Beach housed at the University of Texas Jackson Museum of Earth History in Austin, and he provided data on the history of the collections housed there. We thank D. Domning (Howard University) and D. Bohaska (National Museum of Natural History, Smithsonian Institution) for excellent conversations, assistance with literature, and ana- 
tomical observations. Bohaska, Domning, and A. Millhouse also greatly facilitated our inspection of the type and referred materials of Trichechus manatus bakerorum at the NMNH. J. Ososky, (Division of Mammals, Museum Support Center of the Smithsonian Institution) clarified data for the specimen collected by $D$. Couch that is housed at the NMNH, and C. Carter (Kellogg Special Collec- tions and Archive, NMNH) helped us to discover and access relevant literature. Although such works usually do not garner citations in the literature, the comprehensive compilation and index of sirenian literature by Domning (1996) was particularly helpful to us in placing our discoveries in the broader context of what is known about this group of mammals.

\section{REFERENCES}

Anderson, J.B. 2007. The Formation and Future of the Upper Texas Coast. A Geologist Answers Questions about Sand, Storms, and Living by the Sea. Texas A\&M University Press, College Station, Texas.

Anderson, J.B., Abdulah, K., Sarzalejo, S., Siringan, F., and Thomas, M.A. 1996. Late Quaternary sedimentation and high-resolution sequence stratigraphy of the east Texas shelf, p. 95-124. In De Batist, M. and Jacobs, P. (eds.), Geology of Siliciclastic Shelf Seas. Geological Society of London Special Publications 117. https://doi.org/10.1144/ GSL.SP.1996.117.01.06

Anderson, J.B., Wallace, D.J., Simms, A.R., Rodriguez, A.B., Weight, R.W.R., and Taha, Z.P. 2016. Recycling sediments between source and sink during a eustatic cycle: systems of late Quaternary northwestern Gulf of Mexico Basin. Earth-Science Reviews, 153:111-138. https:// doi.org/10.1016/j.earscirev.2015.10.014

Arnold, J.B. III and Oertling, T.J. 1995. Upper Texas coast underwater archaeological reconnaissance project: Galveston, Chambers, and Jefferson counties. The International Journal of Nautical Archaeology, 24:199-204. https://doi.org/10.1111/j.10959270.1995.tb00732.x

Aronow, S. 1971. Quaternary geology, p. 34-53. In Wesselman, J.B. (ed.), Ground-Water Resources of Chambers and Jefferson Counties, Texas. Texas Water Development Board Report 133.

Bever, M.R. and Meltzer, D.J. 2007. Exploring variation in Paleoindian life ways: The third revised edition of the Texas Clovis Fluted Point Survey. Bulletin of the Texas Archeological Society, 78:65-99.

Brimley, C.S. 1946. The mammals of North Carolina. Installment No. 17. Carolina Tips, 9:2-3.

Brimley, H.H. 1931. The manatee in North Carolina. Journal of Mammalogy, 12:320-321.

de Buffrénil, V., Canoville, A., D'Anastasio, R., and Domning, D.P. 2010. Evolution of sirenian pachyosteosclerosis, a model-case for the study of bone structure in aquatic tetrapods. Journal of Mammalian Evolution, 17:101-120.

Deutsch, C.J., Reid, J.P., Bonde, R.K., Easton, D.E., Kochman, H.I., and O'Shea, T.J. 2003. Seasonal movements, migratory behavior, and site fidelity of West Indian manatees along the Atlantic Coast of the United States. Wildlife Monographs, 151:1-77. https://www.jstor.org/ stable/3830830

Domning, D.P. 1996. Bibliography and index of the Sirenia and Desmostylia. Smithsonian Contributions to Paleobiology, 80:1-611. https://doi.org/10.5479/si.00810266.80.1

Domning, D.P. 2005. Fossil Sirenia of the West Atlantic and Caribbean Region, VII, Pleistocene Trichechus manatus Linnaeus, 1758. Journal of Vertebrate Paleontology, 25:685-701. https:/ /doi.org/10.1671/0272-4634(2005)025[0685:FSOTWA]2.0.CO;2

Domning, D.P. and de Buffrénil, V. 1991. Hydrostasis in the Sirenia: quantitative data and functional interpretations. Marine Mammal Science, 7:331-368. https://doi.org/10.1111/ j.1748-7692.1991.tb00111.x

Domning, D.P., Morgan, G.S., and Ray, C.E. 1982. North American Eocene sea cows (Mammalia: Sirenia). Smithsonian Contributions to Paleobiology, 52:1-69. https://doi.org/ 10.5479/si.00810266.52.1

Fernandez, S. and Jones, S.C. 1990. Manatee stranding on the coast of Texas. The Texas Journal of Science, 42:103. 
Fertl, D., Schiro, A.J., Regan, G.T., Beck, C.A., Adimey, N., Price-May, L., Amos, A., Worthy, G.A.J., and Crossland, R. 2005. Manatee occurrence in the northern Gulf of Mexico, west of Florida. Gulf and Caribbean Research, 17:69-94. https://doi.org/10.18785/gcr.1701.07

Gallagher, W.B., Parris, D.C., Grandstaff, B.S., and DeTample, C. 1989. Quaternary mammals from the continental shelf off New Jersey. The Mosasaur: Journal of the Delaware Valley Paleontological Society, 4:101-110.

Garcia-Rodriguez, A.I., Bowen, B.W., Domning, D., Mignucci-Giannoni, A.A., Marmontel, M., Montoya-Ospina, R.A., Morales-Vela, B., Rudin, M., Bonde, R.K., and McGuire, P.M. 1998. Phylogeography of the West Indian manatee (Trichechus manatus): how many populations and how many taxa? Molecular Ecology, 7:1137-1149. https://doi.org/10.1046/j.1365294x.1998.00430.x

Gill, T.N. 1872. Arrangement of the families of mammals with analytical tables. Smithsonian Miscellaneous Collections, 11(1):1-98.

Gunter, G. 1941a. The manatee, a rare Texas mammal. Proceedings of the Texas Academy of Science, 24:12-13.

Gunter, G. 1941b. Occurrence of the manatee in the United States, with records from Texas. Journal of Mammalogy, 22:60-64. https://doi.org/10.2307/1374684

Gunter, G. 1942. Further miscellaneous notes on American manatees. Journal of Mammalogy, 23:89-90. https://doi.org/10.2307/1374861

Gunter, G. and Corcoran, G. 1981. Mississippi manatees. Gulf Research Reports, 7:97-99. https://doi.org/10.18785/grr.0701.16

Hall, D.A. 1998. Clovis site on Gulf Coast yields booty only to waves. Mammoth Trumpet, 13(4):7-12.

Hartman, D.S. 1979. Ecology and behavior of the manatee (Trichechus manatus) in Florida. American Society of Mammalogists Special Publication, 5:1-153. https://doi.org/10.2307/ 1379863

Heisey, V. and Johanson, D. 1977. Cleveland Museum of Natural History. Society of Vertebrate Paleontology News Bulletin, 110:17-18.

Hester, T.R., Collins, M.B., Story, D.A., Turner, E.S., Tanner, P., Brown, K.M., Banks, L.D., Stanford, D., and Long, R.J. 1992. Paleoindian archaeology at McFaddin Beach, Texas. Current Research in the Pleistocene, 9:20-22.

Illiger, C. 1811. Prodromus systematis mammalium et avium additis terminis zoographicus utriusque classis. C. Salfeld, Berolini, Berlin, Germany.

International Commission on Zoological Nomenclature. 1999. International Code of Zoological Nomenclature. Fourth Edition. The International Trust for Zoological Nomenclature, London, United Kingdom

Jones, J.K., Jr. and Johnson, R.R. 1967. Sirenians, p. 366-373. In Anderson, S. and Jones, J.K., Jr. (eds.), Recent Mammals of the World. A Synopsis of Families. The Ronald Press Company, New York.

Lawson, R.M. 2012. Frontier Naturalist. Jean Louis Berlandier and the Exploration of Northern Mexico and Texas, University of New Mexico Press, Albuquerque, New Mexico.

Lefebvre, L.W., Marmontel, M., Reid, J.P., Rathbun, G.B., and Domning, D.P. 2001. Status and biogeography of the West Indian manatee, p. 425-474. In Woods, C.A. and Sergiles, F.E. (eds.), Biogeography of the West Indies. Patterns and Perspectives. Second Edition. CRC Press, Boca Raton.

Linnaeus, C. 1758. Systema naturæ per Regna Tria Naturæ, secundum Classes, Ordines, Genera, Species, cum Characteribus, Differentiis, Synonymis, Locis. Editio Decima. Laurentii Salvii, Holmiæ, Stockholm, Sweden.

Long, R.J. 1977. McFaddin Beach. The Patillo Higgins Series of Natural History and Anthropology 1. Spindletop Museum, Lamar University.

Long, R.J. 1986. Two Clovis points from McFaddin Beach, Texas. Ohio Archaeologist, 36:9.

Lowery, G.H., Jr. 1974. The Mammals of Louisiana and Its Adjacent Waters. Louisiana State University Press, Baton Rouge, Louisiana.

McAtee, W.L. 1950. Possible early record of a manatee in Virginia. Journal of Mammalogy, 31:98-99. https://doi.org/10.1093/jmammal/31.1.98-a

Milliken, K.T., Anderson, J.B., and Rodriguez, A.B. 2008. Tracking the Holocene evolution of Sabine Lake through the interplay of eustasy, antecedent topography, and sediment supply variations, Texas and Louisiana, USA, p. 65-88. In Anderson, J. B. and Rodriguez, A. B. 
(eds.), Response of Upper Gulf Coast Estuaries to Holocene Climate Change and Sea-Level Rise. The Geological Society of America Special Paper 443. https://doi.org/10.1130/ 2008.2443(05)

Moore, J.C. 1951a. The range of the Florida manatee. The Quarterly Journal of the Florida Academy of Sciences, 14:1-19.

Moore, J.C. $1951 \mathrm{~b}$. The status of the manatee in the Everglades National Park, with notes on its natural history. Journal of Mammalogy, 32:22-36. https://doi.org/10.2307/1375409

Munsell Color Co. 1929. Munsell Book of Color. A Revision and Extension of "The Atlas of the Munsell Color System". Munsell Color Co., Inc., Baltimore, Maryland.

Nelson, E.W. 1916. The larger North American mammals. The National Geographic Magazine, 30:385-472.

Ortiz, R.M., Worthy, G.A.J., and MacKenzie, D.S. 1998. Osmoregulation in wild and captive West Indian manatees (Trichechus manatus). Physiological Zoology, 71:449-457. https://doi.org/ $10.1086 / 515427$

O'Shea, T.J. 1988. The past, present, and future of manatees in the southeastern United States: Realities, misunderstandings, and enigmas, p. 184-204. In Odom, R.R., Riddleberger, K.A., and Ozier, J.C. (eds.), Proceedings of the Third Southeastern Nongame and Endangered Wildlife Symposium. Georgia Department of Natural Resources, Game and Fish Division, Social Circle, Georgia.

O'Shea, T.J., Beck, C.A., Bonde, R.K., Kochman, H.I., and Odell, D.K. 1985. An analysis of manatee mortality patterns in Florida, 1976-81. Journal of Wildlife Management 49:1-11. https://doi.org/10.2307/3801830

Patterson, L.W. 2000. Comments on a study of McFaddin Beach artifacts. La Tierra, 27(4):15-19.

Powell, J.A. and Rathbun, G.B. 1984. Distribution and abundance of manatees along the northern coast of the Gulf of Mexico. Northeast Gulf Science, 7:1-28. https://doi.org/ 10.18785/negs.0701.01

Quiring, D.P. and Harlan, C.F. 1953. On the anatomy of the manatee. Journal of Mammalogy, 34:192-203. https://doi.org/10.2307/1375620

Reid, J. 1997. Navy tracks manatees with satellites. Endangered Species Bulletin, 22:22-23.

Rodriguez, A.B., Anderson, J.B., Siringan, F.P., and Taviana, M. 2004. Holocene evolution of the east Texas coast and inner continental shelf: Along-strike variability in coastal retreat rates. Journal of Sedimentary Research, 74:405-421. https://doi.org/10.1306/092403740405

Russell, J.D. 1975. Identification of Pleistocene fossils from McFaddin Beach, Texas. Unpublished MS Thesis, Lamar University, Beaumont, Texas, USA.

Schwartz, F.J. 1995. Florida manatees, Trichechus manatus (Sirenia: Trichechidae), in North Carolina 1919-1994. Brimleyana, 22:53-60.

Simms, A.R., Lambeck, K., Purcell, A., Anderson, J.B., and Rodriguez, A.B. 2007. Sea-level history of the Gulf of Mexico since the Last Glacial Maximum with implications for the melting history of the Laurentide ice sheet. Quaternary Science Reviews, 26:920-940. https://doi.org/ 10.1016/j.quascirev.2007.01.001

Stright, M.J., Lear, E.M., and Bennett, J.F. 1999. Spatial Data Analysis of Artifacts Redeposited by Coastal Erosion: A Case Study of McFaddin Beach, Texas. OCS Study MMS 99-0068. Prepared for U. S. Department of the Interior Minerals Management Service, Herndon, Virginia.

True, F.W. 1884a. Great International Fisheries Exhibition. London, 1883. United States of America. H. Catalogue of the Aquatic Mammals Exhibited by the United States National Museum, Government Printing Office, Washington, D.C.

True, F.W. 1884b. The sirenians or sea-cows, p. 114-136. In The Fisheries and Fishery Industries of the United States. Prepared through the Co-operation of the Commissioner of Fisheries and the Superintendent of the Tenth Census by George Brown Goode Assistant Director of the U. S. National Museum and a Staff of Associates. Section I. Natural History of Useful Aquatic Animals with an Atlas of Two Hundred and Seventy-Five Plates. United States Commission of Fish and Fisheries, Government Printing Office, Washington, D.C.

Tveten, J.L. 1982. Coastal Texas: Water, Land, and Wildlife. Texas A\&M University Press, College Station, Texas.

Wallace, M. 2015. The Bolivar Peninsula. Arcadia Publishing. Charleston, South Carolina.

Westgate, J.W. 1990. Uintan land mammals (excluding rodents) from an estuarine facies of the Laredo Formation (Middle Eocene, Claiborne Group) of Webb County, Texas. Journal of Paleontology, 64:454-468. https://doi.org/10.1017/S0022336000018709 
Bell et al.: Pleistocene manatees in Texas

Williams, M.E. and Domning, D.P. 2004. Pleistocene or post-Pleistocene manatees in the Mississippi and Ohio River valleys. Marine Mammal Science, 20:167-176. https://doi.org/ 10.1111/j.1748-7692.2004.tb01148.x

Würsig, B., Jefferson, T.A., and Schmidly, D.J. 2000. The Marine Mammals of the Gulf of Mexico. Texas A\&M University Press, College Station, Texas. 